
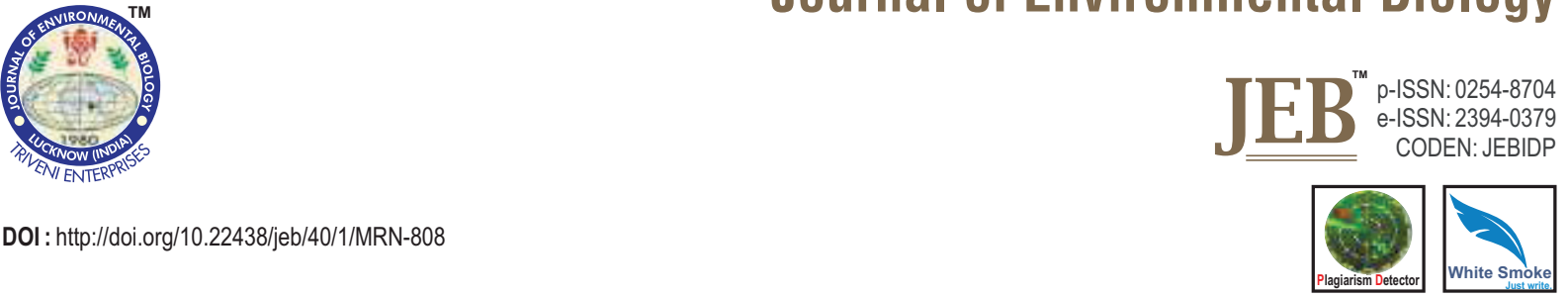

\title{
Modulation of salt-stress tolerance of niger (Guizotia abyssinica), an oilseed plant, by application of salicylic acid
}

\begin{tabular}{lll}
\hline Paper received: 11.12 .2017 & Revised received: $14.03 .2018 \quad$ Re-revised received: 02.04 .2018
\end{tabular}

\section{Authors Info \\ A. Husen ${ }^{1}$, M. Iqbal $^{2 *}$, N. Khanam ${ }^{3}$ I.M. Aref', S.S. Sohrab ${ }^{5}$ and G. Masresha ${ }^{1}$ \\ 'Department of Biology, College of Natural and Computational Sciences, University of Gondar, Gondar, 6200, Ethiopia \\ ${ }^{2}$ Department of Botany, School of Chemical \& Biological Sciences, Jamia Hamdard, New Delhi-110 062 India \\ ${ }^{3}$ Centre of Food Technology, Institute of Professional Studies, Faculty of Science, University of Allahabad-211 002, India \\ ${ }^{4}$ Department of Plant Production, College of Food and Agricultural Sciences, King Saud University, Riyadh, 11451, Saudi Arabia \\ ${ }^{5}$ Special Infectious Agents Unit, King Fahd Medical Research Centre, King Abdulaziz University, Jeddah, 21589, Saudi Arabia}

*Corresponding Author Email : iqbalg5@yahoo.co.in

\section{Edited by \\ Dr. Renu Munjal}

Reviewed by Dr. Radhamani Jalli Dr. R. B. Raizada

\section{Abstract}

Aim : This study aims at exploring the interactive effect of salinity, a known inhibitor of plant growth,and salicylic acid (SA), a growth promoter, on niger [Guizotia abyssinica (L.f.) Cass], an oilseed crop plant, by assessing its growth, metabolism and defence system.

Methodology : In a pot experiment, 4-week-old seedlings of niger were treated with $\mathrm{NaCl}$ (50, 100 and 150 $\mathrm{mM}$ added to the soil) and SA (1 mM aqueous solution sprayed on foliage) and watered regularly with $100 \%$ field capacity. A total of 8 treatments, including the control, were maintained for 8 weeks. Nine-week-old seedlings were sampled to analyze the growth attributes, plant water status, photosynthetic traits, lipidperoxidation level, and activity of antioxidant enzymes.

Results : Salinity treatments inhibited plant growth significantly, as evident from a dosedependent reduction in size and biomass of roots and shoots. The reduction in stem basal diameter was significant only with $150 \mathrm{mM} \mathrm{NaCl}$, a dose which also induced oxidative stress and enhanced lipid peroxidation. Salinity also reduced photosynthetic efficiency by inhibiting chlorophyll synthesis, nitrate reductase activity, chlorophyll fluorescence, stomatal conductance, net photosynthetic and transpiration rates, and plant water status. Reduction in relative water content was significant only at $150 \mathrm{mM}$ of $\mathrm{NaCl}$. High salinity also increased proline production and activity of antioxidant enzymes. Application of SA alone usually caused positive but nonsignificant effects on photosynthesis and growth parameters. SA application in combination with salt stress mitigated the salinity-induced adverse effects on growth and photosynthetic attributes. Moreover, upregulation of antioxidant enzymes
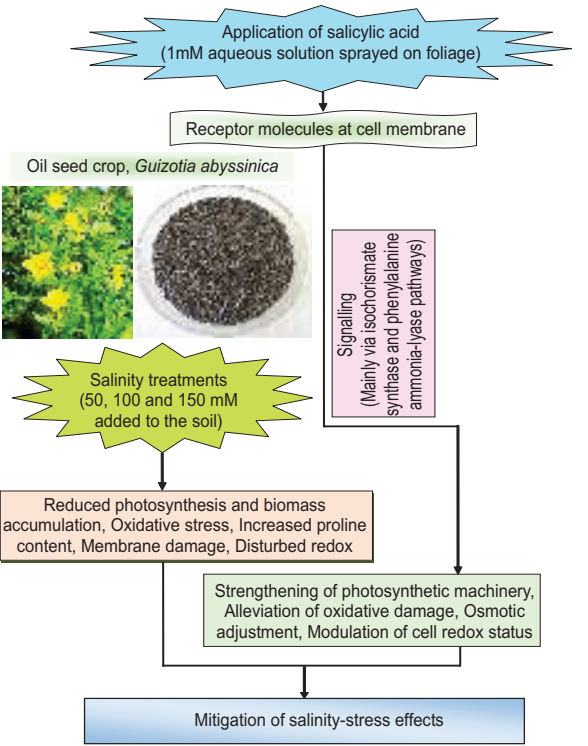
evoked by salinity was further enhanced.

Interpretation : Salinity hampered the overall performance of the crop, but SA application fortified its salttolerance capacity by alleviating the membrane injury and improving the assimilatory activities, plant water status and defense arsenal, thus reducing the adverse effects of salt stress on foliar functions and plant growth.

Key words: Antioxidant enzymes, Leaf characteristics, Oxidative stress, Photosynthesis, Tolerance

How to cite: Husen, A., M. Iqbal, N. Khanam, I.M. Aref, S.S. Sohrab and G. Masresha: Modulation of salt-stress tolerance of niger (Guizotia abyssinica), an oilseed plant, by application of salicylic acid. J. Environ. Biol., 40, 96-104 (2019). 


\section{Introduction}

The growth and yield status of crop plants grown under abiotic stresses is reflected from the level of their water use efficiency (WUE), as also from the maximum quantum efficiency of PS-II measured in terms of chlorophyll fluorescence (Fv/Fm) (Embiale et al., 2016; Husen et al., 2014, 2016). Under stressful condition, photosynthetic efficiency is lowered due to limited $\mathrm{CO}_{2}$ intake by stomata and mesophyll, and the biochemical damage of the chloroplast, the extent of which corresponds to the time duration and intensity of the stress applied (Husen et al., 2014; Bashir et al., 2015). Different external factors including the environmental components, nutrients as well as pollutants are known to cause interactive (antagonistic, synergistic or additive) effects on plants (Abdin et al., 2003; Umar et al., 2010, 2011; Siddiqui et al., 2015).

Soil salinity is a major constraint that limits agricultural productivity. It has destroyed nearly 45 million ha irrigated land all over the world (Pitman and Lauchli, 2002) and about $50 \%$ of the total arable land is likely to be lost by the year 2050 due to continued salinization. Salinity causes significant reductions in growth, water status and biomass production in plants and alters their physiological responses (Qureshi et al., 2013; Husen et al., 2016; Hussein et al., 2017). Plant productivity is hampered normally because of the ionic and osmotic imbalance in cells due to salinity (Arshi et al., 2010, 2012). High salinity stress causes stomatal closure, chlorophyll decline, reduced photosynthesis, and generates reactive oxygen species (ROS) that hampers is membrane function and damage cell plastids by accelerating the membrane-lipid peroxidation, causing the electrolyte leakage (Talaat et al., 2015). Salinity also inhibits uptake and reduction of $\mathrm{No}_{3}$, which limits $\mathrm{N}$ assimilation and plant growth (Silveira et al., 2001). In order to withstand the harsh impacts of ROS, plants have evolved antioxidant defence mechanisms that involve enzymatic as well as non-enzymatic components and operate to enhance plant resistance to oxidative stress (Bashir et al., 2007; Yousuf et al., 2015).

External supply of plant growth regulators (PGRs) may trounce the internal PGR deficiency and help the plant resist against stresses (Fahad et al., 2014; Siddiqi and Husen, 2017). Like many other PGRs such as abscisic acid, auxins, cytokinins, gibberellic acid, brassino steroid, jasmonates and ethylene, salicylic acid (SA), a phenolic growth regulator, offers protection against stresses including salinity (Jayakannan et al., 2015; Khan et al., 2015), possibly by facilitating the biosynthesis of soluble proteins and thus, improving the plant adaptation to stress (Mutlu et al., 2013). Expression of 59 proteins involved in various cell responses, metabolic processes and antioxidant reactions was induced by SA application in cucumber (Hao et al., 2012). Increased plant tolerance to salinity stress can, therefore, be linked to the SA-induced accumulation of proteins in salinityaffected plants. In a recent study, SA application strengthened the ROS-scavenging system in Brassica napus cultivars by rehabilitating the cell organelles injured by a chromium-caused stress (Gill et al., 2016); combined treatments of chromium (Cr) and $\mathrm{SA}$ accelerated the expression of antioxidative genes in the cultivars studied. In another study, SA application decreased the levels of hydrogen peroxide $\left(\mathrm{H}_{2} \mathrm{O}_{2}\right)$, malondialdehyde (MDA) and electrolyte leakage and improved the activity of antioxidant enzymes in Artemisia aucheri grown under the polyethylene glycol (PEG) simulated drought stress that had caused alteration in plasma membrane thickness, shape of nucleus, number of nucleoli and the form of thylakoid membranes and plastoglobuli (Abbaspour and Ehsanpour, 2016). Thus, as a signal molecule, SA enhances the performance of enzymatic antioxidants and reduces the production of ROS, as observed in a variety of crop plants grown under salt stress (Nazar et al., 2015; Jini and Joseph, 2017).

In Ethiopia, the soils in the Rift Valley, Awash Valley and other lowland areas are predominantly salt-affected (Taddese and Bekele, 1996; Tsige et al., 2000). The problem is likely to become more severe in the coming years due to lack of suitable management practices and a growing tilt towards heavy-irrigation agriculture. Niger (Guizotia abyssinica (L.f.) Cass.) of family Asteraceae is an oilseed plant commonly cultivated in Ethiopia and India. It represents $50 \%$ and only $3 \%$ of the total oilseed production in Ethiopia and India, respectively (Husen et al., 2012). The present study attempts to determine whether SA affects the salinity-caused changes in leaf-water status, wateruse efficiency, foliar gas exchange, chlorophyll content, proline accumulation, and activity of antioxidant enzymes in G. abyssinica, and if so, to what extent.

\section{Materials and Methods}

Experimental set up : The study was carried out at the University of Gondar. The mean maximum and minimum daily temperatures during the period of this study were recorded to be $29 \pm 1$ and $18 \pm 1^{\circ} \mathrm{C}$, respectively, with a relative humidity around $50 \%$. Seeds of niger (Guizotia abyssinica var Fogera) obtained from Gondar Agricultural Research Centre were surface-sterilized by keeping in $80 \%$ ethanol for $15 \mathrm{~min}$, washed repeatedly with distilled water and then sown in plastic tray containing a mixture of soil $(75 \%)$ and farmyard manure $(25 \%)$. Two weeks after germination, the selected seedlings of uniform size were transferred to large plastic pots of $25 \mathrm{~cm}$ width and $26 \mathrm{~cm}$ height, filled with nearly 8.5 $\mathrm{kg}$ media (soil and FYM in 3:1 ratio). Three seedlings per pot were sown $2 \mathrm{~cm}$ deep in the amended soil and irrigated daily with tap water at $100 \%$ field capacity (FC) for the next 2 weeks during which the plants must have acclimatized to the new environment. The soil used was sandy loam, comprising of $62.56 \%$ sand, $14.88 \%$ clay and $22.56 \%$ silt, and having a pH of 7.23 and EC of $0.69 \mathrm{~ms} \mathrm{~cm}^{-1}$. After acclimatization (4 weeks after germination), a randomized design was adopted with 5 replications per treatment and 3 plants per replication.

SA application and salt treatments : Aqueous solution of $1 \mathrm{mM}$ salicylic acid (SD Line-Chem Limited, Mumbai, India) was sprayed on the aerial plant parts four times (at one-week interval) starting from the fifth week after germination up to the eighth 
week. The surface of the pot soil was covered with plastic sheet during the spray in order to avoid the access of SA solution to the root system. Simultaneously (i.e. 5 weeks after germination), the soil in pots was treated with $\mathrm{NaCl}$ concentrations (50, 100 and 150 $\mathrm{mM}$ ) and watered regularly with $100 \%$ field capacity. A total of 8 treatments, viz. T1 (control); T2 (1 $\mathrm{mM} \mathrm{SA}) ;$ T3 (50mM NaCl); T4 (100 mM NaCl); T5 (150 mM NaCl); T6 (50 mM NaCl + 1 mM SA); $\mathrm{T} 7(100 \mathrm{mM} \mathrm{NaCl}+1 \mathrm{mM} \mathrm{SA})$ and T8 (150 mM NaCl + 1mM SA) were thus maintained. $\mathrm{NaCl}$ dissolved in tap water was supplied (300 $\mathrm{ml}$ per pot) to T3-T8 every second day, from the fifth week onwards, while only tap water was used for T1 and T2. Sampling was done by uprooting the plants when they were 9-week old.

Plant growth and biomass accumulation : Parameters related to pant-growth \{length of root and stem $(\mathrm{cm})$, ground-line basal stem diameter $(\mathrm{mm})$, and number of opened leaves $\}$ and leaf morphology $\left\{\right.$ length $(\mathrm{mm})$, width $(\mathrm{mm})$ and area $\left.\left(\mathrm{mm}^{2}\right)\right\}$ were analysed for each treatment from the gently uprooted seedlings. The ground-line basal diameter of the stem was measured with the help of electronic digital calliper, whereas the foliar dimensions were measured with a leaf area meter (AM 300, ADC Bio Scientific Ltd, UK). Dry mass (DM) of roots, stems and leaves was obtained separately by an electronic digital balance (CY510, Citizen Scale, Poland). Data obtained for each parameter are based on five replications.

Chlorophyll concentration and fluorescence : Chlorophyll content of fresh leaf was extracted in dimethyl sulfoxide (DMSO), following the method of Hiscox and Israelstam (1979). The contents of chlorophylls $a$ and $b$ were calculated by the formulae given by Arnon (1949) and expressed in $\mathrm{mg} \mathrm{g}^{-1}$ f.wt. Following Hussein et al. (2017), chlorophyll fluorescence (Fv/Fm) of leaves, which denotes maximum quantum yield of PS II, was determined by measuring the basal non-variable fluorescence (Fo), the maximal fluorescence induction (Fm), and variable fluorescence (Fv) of chlorophyll with the help of a portable Multi-Mode Chlorophyll Fluorimeter (Opti-Sciences, Inc., USA) during the forenoon period, and using the formula $\mathrm{Fv} / \mathrm{Fm}=(\mathrm{Fm}-\mathrm{Fo}) / \mathrm{Fm}$.

Foliar gas exchange, Nitrate reductase activity and leaf water status : Leaf gas exchange was estimated by a portable IRGA system (ADC Bio Scientific Limited, U.K.) in the forenoon period so as to determine the stomatal conductance ( $g s)$, net photosynthetic rate $(P n)$ and transpiration rate $(E)$ in fully expanded attached leaves, as described earlier (Hussein etal., 2017).

Activity of NR in the leaf was determined by employing the intact tissue assay method of Jaworski (1971), and expressed in $\mathrm{nMNO}_{2} \mathrm{~g}^{-1}$ f.wt. $\mathrm{hr}^{-1}$.

Fresh weight (FW), turgid weight (TW) and dry weight (DW) of leaves were obtained for calculating the relative water content (RWC) of fully developed leaves with the help of the following equation:

$$
R W C=\{(F W-D W) \div(T W-D W)\} \times 100
$$

Water use efficiency (WUE) for photosynthesizing leaf is defined as the ratio of photosynthesis to water loss through transpiration. It was estimated as WUE $=P n / E$.

Lipid peroxidation (TBARS content) : The amount of total 2thiobarbituric acid reactive substances (TBARS), expressed as malondialdehyde (MDA) equivalents, provides estimates of the extent of oxidative damage to lipids in the leaf tissue. TBARS contents were estimated following the method of Cakmak and Horst (1991), which involves the use of trichloroacetic acid (TCA) and thiobarbituric acid (TBA), and is expressed in nmol $\mathrm{g}^{-1}$ f.wt.

Proline content : Proline content was estimated by the method of Bates et al. (1973), which involves processing of the supernatant obtained by homogenizing the leaf samples in 3\% sulfosalicylic acid and centrifuging at 10,000 rpm. The absorbance of proline, extracted with toluene, was read at $520 \mathrm{~nm}$, and the proline content was expressed in $\mu \mathrm{g} \mathrm{g}{ }^{-1}$. .wt.

Antioxidant enzymes assay : Leaf material $(500 \mathrm{mg})$ from each sample was homogenized in the extraction buffer comprising of $0.5 \%$ Triton $\mathrm{X}-100\left[\mathrm{C}_{14} \mathrm{H}_{22} \mathrm{O}\left(\mathrm{C}_{2} \mathrm{H}_{4} \mathrm{O}\right)_{n}\right]$ and $1 \%$ polyvinylpyrrolidone $\left[\left(\mathrm{C}_{6} \mathrm{H}_{9} \mathrm{NO}\right)_{n}\right]$ in $100 \mathrm{mM}$ potassium phosphate buffer (pH 7.0). Chilled mortar and pestle were used for preparing the crude extraction. The homogenate was then centrifuged at 15,000 rpm (20 min) at $4^{\circ} \mathrm{C}$, and the supernatant was used for enzymatic assays. The activity of catalase (CAT: E.C.1.11.1.6), superoxide dismutase (SOD: E.C.1.15.1.1) and peroxidase (POX: E.C.1.11.1.7) was estimated following the methods of Chandlee and Scandalios (1984), Beauchamp and Fridovich (1971) and Kumar and Khan (1982), respectively, and expressed in $\mathrm{U} \mathrm{mg}^{-1}$ protein.

Statistical analysis : The data obtained were statistically analyzed using the Statistical Package for Social Sciences (SPSS) software (version 16.0), and a two-way analysis of variance (ANOVA) was calculated to find out the significance of difference among various parameters in order to determine the effect of salinity, SA and their interaction on the species studied. Duncan's test was applied for comparing the means (at $p<0.05$ ).

\section{Results and Discussion}

Salicylic acid $(1 \mathrm{mM})$ application caused a significant positive impact on shoot length, number of leaves and leaf width, showing a $7-8 \%$ gain with reference to the control (Table 1). Salinity treatments inhibited root length, shoot length, and the abundance, area, width and length of leaves in a dose-dependent manner. At high concentration of salinity $(150 \mathrm{mM} \mathrm{NaCl})$, these parameters were reduced by about $34,43,61,27,27$ and $27 \%$, respectively in comparison to the control. The variation in the stem basal diameter was non-significant at 50 and $100 \mathrm{mM} \mathrm{NaCl}$, but significantly high (32\%) at higher level of salinity. Combined applications of SA and salt resulted in a considerable alleviation of the salt-induced losses (Table 1). Similar trends of variation appeared with biomass production of different plant parts. SA 
Table 1 : Effects of salt stress and salicylic acid treatments on the growth of Guizotia abyssinica

\begin{tabular}{|c|c|c|c|c|c|c|c|}
\hline Treatments & $\begin{array}{l}\text { Root length } \\
\text { (cm) }\end{array}$ & $\begin{array}{l}\text { Shoot length } \\
(\mathrm{cm})\end{array}$ & $\begin{array}{l}\text { Stem basal } \\
\text { diameter }(\mathrm{mm})\end{array}$ & $\begin{array}{l}\text { Number of } \\
\text { leaves }\end{array}$ & $\begin{array}{l}\text { Leaf area } \\
(\mathrm{mm})\end{array}$ & $\begin{array}{l}\text { Leaf width } \\
(\mathrm{mm})\end{array}$ & $\begin{array}{l}\text { Leaf length } \\
(\mathrm{mm})\end{array}$ \\
\hline Control & & $45.51 \pm 1.56^{b}$ & & $18.87 \pm 0.78^{b}$ & $10394.87 \pm 265.49^{a}$ & $65.83 \pm 1.67^{b}$ & $137.27 \pm 6.04^{a}$ \\
\hline $1 \mathrm{mM} \mathrm{SA}$ & $\begin{array}{l}9.41 \pm 0.65^{\mathrm{a}} \\
(13.78)\end{array}$ & $\begin{array}{l}48.87 \pm 2.00^{\mathrm{a}} \\
(7.38)\end{array}$ & $\begin{array}{l}10.22 \pm 0.62^{\mathrm{a}} \\
(9.30)\end{array}$ & $\begin{array}{l}20.49 \pm 0.57^{\mathrm{a}} \\
(8.59)\end{array}$ & $\begin{array}{l}11027.42 \pm 294.17^{\mathrm{a}} \\
(6.09)\end{array}$ & $\begin{array}{l}70.95 \pm 1.47^{\mathrm{a}} \\
(7.78)\end{array}$ & $\begin{array}{l}140.55 \pm 9.52^{\mathrm{a}} \\
(2.39)\end{array}$ \\
\hline 50 mM NaCl & $\begin{array}{l}7.58 \pm 0.18^{b} \\
(8.34)\end{array}$ & $\begin{array}{l}39.48 \pm 2.00^{d} \\
(13.25)\end{array}$ & $\begin{array}{l}9.26 \pm 0.68^{\mathrm{a}} \\
(0.96)\end{array}$ & $\begin{array}{l}14.73 \pm 0.69^{\circ} \\
(21.94)\end{array}$ & $\begin{array}{l}9607.07 \pm 226.51^{b} \\
(7.58)\end{array}$ & $\begin{array}{l}53.32 \pm 1.87^{\circ} \\
(19.00)\end{array}$ & $\begin{array}{l}116.83 \pm 5.27^{\circ} \\
(14.89)\end{array}$ \\
\hline $100 \mathrm{mM} \mathrm{NaCl}$ & $\begin{array}{l}6.85 \pm 0.40^{\circ} \\
(17.17)\end{array}$ & $\begin{array}{l}36.02 \pm 1.81^{\mathrm{d}} \\
(20.85)\end{array}$ & $\begin{array}{l}9.13 \pm 0.40^{\mathrm{a}} \\
(2.35)\end{array}$ & $\begin{array}{l}12.13 \pm 0.69^{d} \\
(35.72)\end{array}$ & $\begin{array}{l}8403.49 \pm 233.81^{d} \\
(19.16)\end{array}$ & $\begin{array}{l}52.27 \pm 1.50^{\circ} \\
(20.60)\end{array}$ & $\begin{array}{l}107.81 \pm 4.15^{d} \\
(21.46)\end{array}$ \\
\hline $150 \mathrm{mM} \mathrm{NaCl}$ & $\begin{array}{l}5.47 \pm 0.40^{d} \\
(33.86)\end{array}$ & $\begin{array}{l}25.73 \pm 2.46^{\bullet} \\
(43.46)\end{array}$ & $\begin{array}{l}6.33 \pm 0.36^{\circ} \\
(32.30)\end{array}$ & $\begin{array}{l}7.42 \pm 0.72 \\
(60.68)\end{array}$ & $\begin{array}{l}7584.50 \pm 237.53^{\mathrm{e}} \\
(27.40)\end{array}$ & $\begin{array}{l}48.28 \pm 1.30^{\circ} \\
(26.66)\end{array}$ & $\begin{array}{l}100.42 \pm 3.79^{\circ} \\
(26.84)\end{array}$ \\
\hline $\begin{array}{l}50 \mathrm{mM} \mathrm{NaCl} \\
+1 \mathrm{mM} \mathrm{SA}\end{array}$ & $\begin{array}{l}8.13 \pm 0.20^{\mathrm{a}} \\
(1.69)\end{array}$ & $\begin{array}{l}43.66 \pm 2.04 b^{\circ} \\
(4.07)\end{array}$ & $\begin{array}{l}9.77 \pm 0.76^{\mathrm{a}} \\
(4.49)\end{array}$ & $\begin{array}{l}17.39 \pm 0.98^{b} \\
(7.84)\end{array}$ & $\begin{array}{l}10247.67 \pm 227.34^{\mathrm{a}} \\
(1.42)\end{array}$ & $\begin{array}{l}63.87 \pm 1.77^{\circ} \\
(2.98)\end{array}$ & $\begin{array}{l}125.57 \pm 3.32^{b} \\
(8.52)\end{array}$ \\
\hline $\begin{array}{l}100 \mathrm{mM} \mathrm{NaCl} \\
+1 \mathrm{mM} \mathrm{SA}\end{array}$ & $\begin{array}{l}7.23 \pm 0.39^{\mathrm{b}} \\
(12.58)\end{array}$ & $\begin{array}{l}41.59 \pm 2.36^{c} \\
(8.61)\end{array}$ & $\begin{array}{l}9.21 \pm 0.49^{\mathrm{a}} \\
(1.50)\end{array}$ & $\begin{array}{l}14.62 \pm 0.88^{\mathrm{c}} \\
(22.52)\end{array}$ & $\begin{array}{l}9043.39 \pm 299.17^{\circ} \\
(13.00)\end{array}$ & $\begin{array}{l}60.32 \pm 2.98^{\mathrm{b}} \\
(8.37)\end{array}$ & $\begin{array}{l}120.36 \pm 4.25^{c} \\
(12.32)\end{array}$ \\
\hline $\begin{array}{l}150 \mathrm{mM} \mathrm{NaCl} \\
+1 \mathrm{mM} \mathrm{SA}\end{array}$ & $\begin{array}{l}7.01 \pm 0.42 b^{c} \\
(15.24)\end{array}$ & $\begin{array}{l}35.73 \pm 2.67^{d} \\
(21.49)\end{array}$ & $\begin{array}{l}7.01 \pm 0.46^{b} \\
(25.03)\end{array}$ & $\begin{array}{l}9.16 \pm 0.65^{\mathrm{e}} \\
(51.46)\end{array}$ & $\begin{array}{l}8019.48 \pm 229.88^{d} \\
(22.85)\end{array}$ & $\begin{array}{l}54.13 \pm 1.50^{b} \\
(17.77)\end{array}$ & $\begin{array}{l}110.78 \pm 4.06^{d} \\
(19.30)\end{array}$ \\
\hline
\end{tabular}

Each value represents the mean \pm SE of five replicates.Values followed by different letters indicate significant differences $(p<0.05)$ according to the Duncan's test. Values in parentheses represent percent variation from the control

application alone caused a non-significant increase over the control in the dry mass of roots, stem and leaves at $p<0.05$ level. However, salinity stress significantly inhibited the plant biomass production in a dose-dependent manner, showing a reduction in dry mass up to $75 \%$ in roots, $73 \%$ in stem and $66 \%$ in leaves at $150 \mathrm{mM} \mathrm{NaCl}$, compared to the control (Table 2). Further, the interactive effect of salinity and SA treatments was on the whole positive and significant, thus decreasing the negative impact of salt stress on the accumulation of dry mass in different parts of the plant (Table 2).

It is known that salinity stress disturbs the homeostasis in plant water potential and ion distribution at the cellular and wholeplant levels, and this often leads to molecule injury, altered plant physiology, disturbed metabolism, growth arrest and even death of the plant (Arshi et al., 2012; Hussein et al., 2017). Salinity affects water imbibition by roots due to low osmotic potential of the substrate, besides hampering the phenomena of photosynthesis, accumulation of compatible solutes, nutrient homeostasis, protein synthesis and modulation of enzymatic and nonenzymatic antioxidants (Qureshi et al., 2013; Bagheri et al., 2015; Yousuf et al., 2016a, 2016b, 2017). Thus, the growth decline in G. abyssinica might be due to a reduced leaf area, low production of photo assimilates, and imbalance in plant water status.

The positive role of SA treatment in reducing the salinitycaused damage goes in line with several earlier studies. This might be linked to the capacity of SA for membrane protection, which is likely to enhance antioxidative functions and hence, the plant tolerance to salinity stress (Khan et al., 2015; Nazar et al., 2015). The degree of effectiveness depends on SA concentration, duration of treatment and the plant species under study. It was described to be stimulatory for growth at low (less than $100 \mu \mathrm{M}$ ) concentrations but inhibitory at high (more than $1 \mathrm{mM}$ ) concentrations (Rivas-San Vicente and Plasencia, 2011). In the present study, plants treated with SA (1mM SA) displayed a higher chlorophyll level than the control; but the increase was non-significant at $p<0.05$ level (Table 3). On the other hand, salt stress significantly reduced the contents of $\mathrm{chl} a$ and $\mathrm{chl} b$ in a dose-dependent manner, showing the maximum reduction (by about $45 \%$ and $43 \%$, respectively, in comparison to the control) at $150 \mathrm{mM} \mathrm{NaCl}$. This could be because of a possible oxidation of chlorophyll and allied pigments, and the non-stability of pigmentprotein complex under the influence of salinity (Stepien and Klobus, 2006). The interaction of salinity and SA displayed a

Table 2 : Effects of salt stress and salicylic acid treatments on the dry mass (DM) of Guizotia abyssinica

\begin{tabular}{llll}
\hline Treatments & Root DM (g) & Stem DM (g) & Leaves DM (g) \\
\hline Control & $0.56 \pm 0.020^{\mathrm{a}}$ & $1.76 \pm 0.012^{\mathrm{a}}$ & $0.89 \pm 0.033^{\mathrm{a}}$ \\
$1 \mathrm{mM} \mathrm{SA}$ & $0.60 \pm 0.027^{\mathrm{a}}$ & $1.81 \pm 0.019^{\mathrm{a}}$ & $0.96 \pm 0.043^{\mathrm{a}}$ \\
& $(7.14)$ & $(2.84)$ & $(7.78)$ \\
$50 \mathrm{mM} \mathrm{NaCl}$ & $0.35 \pm 0.013^{\mathrm{c}}$ & $0.93 \pm 0.019^{\mathrm{c}}$ & $0.73 \pm 0.013^{\mathrm{b}}$ \\
& $(37.50)$ & $(47.16)$ & $(17.98)$ \\
$100 \mathrm{mM} \mathrm{NaCl}$ & $0.25 \pm 0.017^{\mathrm{e}}$ & $0.78 \pm 0.014^{\mathrm{e}}$ & $0.44 \pm 0.019^{\mathrm{d}}$ \\
& $(55.36)$ & $(55.68)$ & $(50.56)$ \\
$150 \mathrm{mM} \mathrm{NaCl}$ & $0.14 \pm 0.018^{\mathrm{g}}$ & $0.47 \pm 0.016^{\mathrm{f}}$ & $0.30 \pm 0.014^{\mathrm{f}}$ \\
& $(75.00)$ & $(73.30)$ & $(66.29)$ \\
$50 \mathrm{mM} \mathrm{NaCl}$ & $0.42 \pm 0.015^{\mathrm{b}}$ & $1.11 \pm 0.013^{\mathrm{b}}$ & $0.75 \pm 0.029^{\mathrm{b}}$ \\
$+1 \mathrm{mM} \mathrm{SA}$ & $(25.00)$ & $(36.93)$ & $(15.73)$ \\
$100 \mathrm{mM} \mathrm{NaCl}$ & $0.31 \pm 0.013^{\mathrm{d}}$ & $0.87 \pm 0.012^{\mathrm{d}}$ & $0.59 \pm 0.011^{\circ}$ \\
$+1 \mathrm{mM} \mathrm{SA}$ & $(44.64)$ & $(50.57)$ & $(33.71)$ \\
$150 \mathrm{mM} \mathrm{NaCl}$ & $0.20 \pm 0.016^{\mathrm{f}}$ & $0.52 \pm 0.016^{\mathrm{e}}$ & $0.38 \pm 0.021^{\mathrm{e}}$ \\
$+1 \mathrm{mM} \mathrm{SA}$ & $(64.29)$ & $(70.45)$ & $(57.30)$ \\
\hline
\end{tabular}

Each value represents the mean \pm SE of five replicates. Values followed by different letters indicate significant differences $(p<0.05)$ according to the Duncan's test. Values in parentheses represent percent variation from the control 
mitigation of salinity effect, possibly by stimulating the Rubis Co activity and pigment biosynthesis. The photochemical efficiency of PSII (Fv/Fm) in G. abyssinica plants was around 0.80; it registered a slight improvement over the control $(0.82)$ at $p<0.05$ level due to application of $1 \mathrm{mM} \mathrm{SA}$. The Fv/Fm values showed a consistent decline under salt stress, with a 25\% decrease at 150 $\mathrm{mM} \mathrm{NaCl}$ in comparison to the control. However, the salt-induced decline in Fv/Fm was greatly reduced (being 10\% instead of 25\%) under the combined effect of SA and salinity (Table 3). Likewise, stomatal conductance $(g s)$ and net photosynthetic rate $(P n)$ in the leaf tissue also showed insignificant variation ( $p<0.05$ level) from the control due to SA application. On the contrary, salt stress reduced these parameters significantly in a dose-dependent manner, with the maximum reduction ( $67 \%$ for gs and $53 \%$ for $P n$ ) occurring at the highest $(150 \mathrm{mM}) \mathrm{NaCl}$ dose. The interactive effect of salinity and SA application was positive for both $g$ s and $P n$, as it significantly mitigated the salt-induced loss at all levels of salinity stress (Table 3). The dose-dependent negative impact of salinity on the efficiency of PS II, which indicates a plausible photochemical alteration in photosynthesis, may vary with the cultivar used and the length of stress duration (Kalaji et al., 2011).

The Fv/Fm value and the electron-transport rate declined by $9-10 \%$ and $20-25 \%$, respectively, in two varieties of sorghum treated with $250 \mathrm{mM} \mathrm{NaCl}$; the photosynthetic rate was influenced basically by stomatal closure (Netondo et al., 2004). The Fv/Fmin Sphaerophysa kotschyana plants remained unaffected up to 150 $\mathrm{mM} \mathrm{NaCl}$, but decreased significantly at a higher (300 mM) dose (Yildiztugay et al., 2014). In a recent study, Fv/Fm ratio and nonphotochemical quenching coefficient (qN) decreased under salt stress and were restored by SA treatments (Mimouni et al., 2016). The Fv/Fm value, duly correlated with photosynthetic parameters and biomass production, is used as an indicator to determine the seedling-stock quality (Husen, 2009; 2013). Salinity inhibits photosynthesis by affecting various parameters such as gas exchange through stomata, concentration of pigments, structure and behaviour of thylakoid membrane, electron transport, antioxidant mechanisms and metabolic processes.

The reduced photosynthesis often leads to a reduced plant productivity, whereas SA application has a restorative effect and enhances $P n$ by reversing the salt-induced stomatal closure. SA pre treatment all eviated the salt-induced inhibition of photosynthesis and plant growth through glycine betaine and ethylene production in Vigna radiata (Khan et al., 2014). SA application on salt-affected plants improved the $P n$ possibly for its positive role with reference to mobilization of nitrate and/or chlorophyll biosynthesis in the tissue (Shi et al., 2006) or by stimulating the Rubisco activity (Khodary, 2004). The effect on photosynthesis is concentration-dependent; low concentrations (less than $10 \mu \mathrm{M}$ ) of SA mitigate the salinity-induced decline in photosynthesis, but the higher (1-5 mM) ones give opposite results (Nazar et al., 2011). SA application (0.5 mM) to Brassica juncea alleviated the adverse effects of salinity and improved $P n$ and plant growth by improving the enzymes action in ascorbateglutathione pathway, thus suggesting that SA helps in maintaining the redox balance under salinity stress (Nazar et al., 2015). Arabidopsis mutant with higher endogenous SA concentration displayed a reduced stomatal aperture and increased salt tolerance (Miura et al., 2013). Given this, the SA-mediated stomatal closure, may be a useful condition for plants.

Activity of nitrate reductase, a rate-limiting enzyme in $\mathrm{N}$ assimilation, increased significantly (by about 3\% over the control) in the leaves of $G$. abyssinica on application of $1 \mathrm{mM} \mathrm{SA}$. On the other hand, salinity reduced the activity, showing the

Table 3 : Effects of salt stress and salicylic acid treatments on chlorophyll content, photosynthetic traits and nitrate reductase (NR) activity in leaves of Guizotia abyssinica

\begin{tabular}{|c|c|c|c|c|c|c|}
\hline Treatments & $\begin{array}{l}\text { Chlorophyll a } \\
\left.\text { (mg g }{ }^{-1} \mathrm{FW}\right)\end{array}$ & $\begin{array}{l}\text { Chlorophyll b } \\
\left(\mathrm{mg} \mathrm{g}^{-1} \mathrm{FW}\right)\end{array}$ & $\begin{array}{l}\text { Chlorophyll } \\
\text { fluorescence }\end{array}$ & $\begin{array}{l}\text { Stomata conductance } \\
\left(\mathrm{mol} \mathrm{m}^{-2} \mathrm{~s}^{-1}\right)\end{array}$ & $\begin{array}{l}\text { Net photosynthetic } \\
\text { rate }\left(\mu \mathrm{mol} \mathrm{m} \mathrm{s}^{-1}\right)\end{array}$ & $\begin{array}{l}\text { NR activity } \\
\left(\mathrm{nM} \mathrm{NO}_{2}-\mathrm{g}^{-1} \mathrm{FW} \mathrm{hr}\right)\end{array}$ \\
\hline Control & $0.33 \pm 0.009^{\mathrm{a}}$ & $0.21 \pm 0.006^{a}$ & $0.80 \pm 0.018^{a b}$ & $0.09 \pm 0.002^{a}$ & $9.29 \pm 0.18^{a}$ & $256.23 \pm 4.02^{b}$ \\
\hline $1 \mathrm{mM} \mathrm{SA}$ & $\begin{array}{l}0.34 \pm 0.008^{\mathrm{a}} \\
(3.03)\end{array}$ & $\begin{array}{l}0.20 \pm 0.007^{\mathrm{a}} \\
(4.76)\end{array}$ & $\begin{array}{l}0.82 \pm 0.014^{\mathrm{a}} \\
(2.50)\end{array}$ & $\begin{array}{l}0.09 \pm 0.003^{\mathrm{a}} \\
(0.00)\end{array}$ & $\begin{array}{l}9.33 \pm 0.15^{\mathrm{a}} \\
(0.43)\end{array}$ & $\begin{array}{l}265.36 \pm 5.48^{\mathrm{a}} \\
(3.56)\end{array}$ \\
\hline $50 \mathrm{mM} \mathrm{NaCl}$ & $\begin{array}{l}0.25 \pm 0.007^{\circ} \\
(24.24)\end{array}$ & $\begin{array}{l}0.16 \pm 0.007^{\circ} \\
(23.81)\end{array}$ & $\begin{array}{l}0.68 \pm 0.017^{d} \\
(15.00)\end{array}$ & $\begin{array}{l}0.06 \pm 0.003^{\circ} \\
(33.33)\end{array}$ & $\begin{array}{l}7.12 \pm 0.17^{d} \\
(23.36)\end{array}$ & $\begin{array}{l}245.82 \pm 5.03^{\circ} \\
(4.06)\end{array}$ \\
\hline $100 \mathrm{mM} \mathrm{NaCl}$ & $\begin{array}{l}0.20 \pm 0.007^{d} \\
(39.39)\end{array}$ & $\begin{array}{l}0.14 \pm 0.006^{d} \\
(33.33)\end{array}$ & $\begin{array}{l}0.66 \pm 0.014^{d} \\
(17.00)\end{array}$ & $\begin{array}{l}0.05 \pm 0.003^{\mathrm{d}} \\
(44.44)\end{array}$ & $\begin{array}{l}5.05 \pm 0.13^{\mathrm{e}} \\
(45.64)\end{array}$ & $\begin{array}{l}238.47 \pm 4.82^{\circ} \\
(6.93)\end{array}$ \\
\hline $150 \mathrm{mM} \mathrm{NaCl}$ & $\begin{array}{l}0.18 \pm 0.008^{e} \\
(45.45)\end{array}$ & $\begin{array}{l}0.12 \pm 0.008^{\mathrm{e}} \\
(42.86)\end{array}$ & $\begin{array}{l}0.60 \pm 0.021^{\mathrm{e}} \\
(25.00)\end{array}$ & $\begin{array}{l}0.03 \pm 0.003^{\circ} \\
(66.67)\end{array}$ & $\begin{array}{l}4.34 \pm 0.11^{\dagger} \\
(53.28)\end{array}$ & $\begin{array}{l}221.53 \pm 4.91^{\mathrm{e}} \\
(13.54)\end{array}$ \\
\hline $\begin{array}{l}50 \mathrm{mM} \mathrm{NaCl} \\
+1 \mathrm{mM} \mathrm{SA}\end{array}$ & $\begin{array}{l}0.30 \pm 0.013^{b} \\
(9.09)\end{array}$ & $\begin{array}{l}0.20 \pm 0.004^{a} \\
(4.76)\end{array}$ & $\begin{array}{l}0.78 \pm 0.016^{b} \\
(2.50)\end{array}$ & $\begin{array}{l}0.07 \pm 0.003^{\mathrm{b}} \\
(22.22)\end{array}$ & $\begin{array}{l}8.35 \pm 0.18^{b} \\
(10.12)\end{array}$ & $\begin{array}{l}260.28 \pm 3.37^{\mathrm{ab}} \\
(1.58)\end{array}$ \\
\hline $\begin{array}{l}100 \mathrm{mM} \mathrm{NaCl} \\
+1 \mathrm{mM} \mathrm{SA}\end{array}$ & $\begin{array}{l}0.28 \pm 0.010^{\circ} \\
(15.15)\end{array}$ & $\begin{array}{l}0.20 \pm 0.005^{\mathrm{a}} \\
(4.76)\end{array}$ & $\begin{array}{l}0.74 \pm 0.012^{\circ} \\
(7.50)\end{array}$ & $\begin{array}{l}0.07 \pm 0.002^{\mathrm{b}} \\
(22.22)\end{array}$ & $\begin{array}{l}7.83 \pm 0.12^{c} \\
(15.72)\end{array}$ & $\begin{array}{l}254.62 \pm 3.66^{b} \\
(0.63)\end{array}$ \\
\hline $150 \mathrm{mM} \mathrm{NaCl}$ & $0.25 \pm 0.008^{c}$ & $0.18 \pm 0.004^{b}$ & $0.72 \pm 0.015^{c}$ & $0.05 \pm 0.004^{d}$ & $6.89 \pm 0.14^{d}$ & $227.64 \pm 5.13^{d}$ \\
\hline$+1 \mathrm{mM} \mathrm{SA}$ & $(24.24)$ & (19.05) & $(10.00)$ & $(44.44)$ & $(25.83)$ & $(11.16)$ \\
\hline
\end{tabular}

Each value represents the mean \pm SE of five replicates. Values followed by different letters indicate significant differences $(p<0.05)$ according to the Duncan's test. Values in parentheses represent percent variation from the control 
maximum (13\%) difference from the control with $150 \mathrm{mM} \mathrm{NaCl}$. On a combined application of SA and salinity, no adverse impact of salinity was visible except at $150 \mathrm{mM}$ salt level where NR activity declined by $11 \%$ with reference to the control (Table 3). These results endorse the observations of Liu et al. (2014), who recorded a low uptake of nitrogen and a reduced activity of $\mathrm{N}$ assimilating enzymes under the impact of salinity. SA has a role in stabilizing the plasma membrane, which must enhance the uptake of nutrients, including nitrate that induces the NR (Campbell, 1999).

Table 4 exhibits the effect of individual and combinatorial treatments of $S A$ and salinity on transpiration rate $(E)$, relative water content (RWC) and water use efficiency (WUE) in $G$. abyssinica. SA application caused insignificant variation $(p<0.05$ level) in these parameters with reference to the control. Nevertheless, salinity treatments reduced $E$ and WUE significantly and in a dose-dependent manner. Under high salinity stress $(150 \mathrm{mM} \mathrm{NaCl})$, both $E$ and WUE were reduced by $31 \%$ and $32 \%$, compared to the control. However, the interactive effect of salinity and SA treatments was positive in the sense that it significantly curtailed the salt-induced decline in both the parameters (Table 4). Besides, the RWC of leaf displayed insignificant reduction at low $(50 \mathrm{mM})$ level of salinity; but a significant reduction of $11 \%$ and $22 \%$ appeared at 100 and 150 $\mathrm{mM}$, respectively with reference to the control. The interactive effect of salinity and SA applications was positive and significant in reducing the loss caused by the salinity (Table 4). Salinity affects water balance and impedes WUE possibly by inhibiting water absorption by roots and then water translocation from roots to the aerial plant parts (Husen et al., 2016). The decline in leaf RWC caused by high salinity causes a loss of turgor and reduces the availability of water for cell expansion (Sekmen et al., 2007).
Table 4 : Effects of salt stress and salicylic acid treatments on plant water relations as measured in leaves of Guizotia abyssinica

\begin{tabular}{llll}
\hline Treatments & $\begin{array}{l}\text { Transpiration rate } \\
\left(\mathrm{mmol} \mathrm{m}^{-2} \mathbf{s}^{-1}\right)\end{array}$ & $\begin{array}{l}\text { Relative water } \\
\text { content }\end{array}$ & $\begin{array}{l}\text { Water-use } \\
\text { efficiency }\end{array}$ \\
\hline Control & $1.85 \pm 0.039^{\mathrm{a}}$ & $90.76 \pm 3.17^{\mathrm{a}}$ & $5.02 \pm 0.14^{\mathrm{a}}$ \\
$1 \mathrm{mM} \mathrm{SA}$ & $1.88 \pm 0.037^{\mathrm{a}}$ & $91.01 \pm 3.05^{\mathrm{a}}$ & $4.96 \pm 0.13^{\mathrm{a}}$ \\
& $(1.62)$ & $(0.28)$ & $(1.20)$ \\
$50 \mathrm{mM} \mathrm{NaCl}$ & $1.54 \pm 0.032^{\mathrm{d}}$ & $86.56 \pm 3.10^{\mathrm{a}}$ & $4.62 \pm 0.12^{\mathrm{c}}$ \\
& $(16.76)$ & $(4.63)$ & $(7.97)$ \\
$100 \mathrm{mM} \mathrm{NaCl}$ & $1.36 \pm 0.031^{\mathrm{e}}$ & $80.47 \pm 2.19^{\mathrm{b}}$ & $3.71 \pm 0.15^{\mathrm{d}}$ \\
& $(24.69)$ & $(11.34)$ & $(26.10)$ \\
$150 \mathrm{mM} \mathrm{NaCl}$ & $1.27 \pm 0.028^{\mathrm{f}}$ & $70.76 \pm 2.21^{\mathrm{d}}$ & $3.42 \pm 0.11^{\mathrm{e}}$ \\
& $(31.35)$ & $(22.04)$ & $(31.87)$ \\
$50 \mathrm{mM} \mathrm{NaCl}$ & $1.75 \pm 0.027^{\mathrm{b}}$ & $88.45 \pm 2.79^{\mathrm{a}}$ & $4.77 \pm 0.11^{\mathrm{ab}}$ \\
$+1 \mathrm{mM} \mathrm{SA}$ & $(5.41)$ & $(2.55)$ & $(4.98)$ \\
$100 \mathrm{mM} \mathrm{NaCl}$ & $1.66 \pm 0.015^{\mathrm{c}}$ & $83.96 \pm 2.04^{\mathrm{ab}}$ & $4.72 \pm 0.10^{\mathrm{b}}$ \\
$+1 \mathrm{mM} \mathrm{SA}$ & $(10.27)$ & $(7.49)$ & $(5.98)$ \\
$150 \mathrm{mM} \mathrm{NaCl}$ & $1.57 \pm 0.031^{\mathrm{d}}$ & $75.18 \pm 2.14^{\mathrm{c}}$ & $4.39 \pm 0.15^{\mathrm{c}}$ \\
$+1 \mathrm{mM} \mathrm{SA}$ & $(15.14)$ & $(17.17)$ & $(12.55)$ \\
\hline
\end{tabular}

Each value represents the mean $\pm \mathrm{SE}$ of five replicates.Values followed by different letters indicate significant differences $(p<0.05)$ according to the Duncan's test.Values in parentheses represent percent variation from the control

The SA-caused restoration of RWC could possibly be an adaptive response towards improving the moistness and maintaining the water balance in plant tissues against the salinity-induced osmotic stress (Rady and Mohamed, 2015). TBARS content in leaves, indicating the rate of lipid peroxidation and hence, the level of oxidative stress varied only slightly $($ at $p<0.05)$ by the application of SA but increased significantly due to salt treatments

Table 5 : Effects of salt stress and salicylic acid treatments on the TBARS, proline contents and antioxidant enzymes activity in leaves of Guizotia abyssinica

\begin{tabular}{|c|c|c|c|c|c|}
\hline Treatments & $\begin{array}{l}\text { TBARS } \\
\left(\mathrm{nmol} \mathrm{g}^{-1} \mathrm{FW}\right)\end{array}$ & $\begin{array}{l}\text { Proline } \\
\left(\mu \mathrm{g} \mathrm{g}^{-1} \mathrm{FW}\right)\end{array}$ & $\begin{array}{l}\text { Superoxide dismutase } \\
\text { (U mg }{ }^{-1} \text { protein) }\end{array}$ & $\begin{array}{l}\text { Catalase } \\
\text { (U mg } \text { m protein) }^{-1}\end{array}$ & $\begin{array}{l}\text { Peroxidase } \\
\text { (U mg }{ }^{-1} \text { protein) }\end{array}$ \\
\hline Control & $4.87 \pm 0.43^{\mathrm{e}}$ & $41.85 \pm 2.31^{\mathrm{e}}$ & $2.51 \pm 0.07^{9}$ & $7.63 \pm 0.31^{9}$ & $42.76 \pm 1.00^{9}$ \\
\hline $1 \mathrm{mM} \mathrm{SA}$ & $\begin{array}{l}4.54 \pm 0.48^{\circ} \\
(6.78)\end{array}$ & $\begin{array}{l}39.43 \pm 2.46^{e} \\
(5.78)\end{array}$ & $\begin{array}{l}2.85 \pm 0.09^{\circ} \\
(13.55)\end{array}$ & $\begin{array}{l}10.81 \pm 0.22^{\mathrm{e}} \\
(41.68)\end{array}$ & $\begin{array}{l}48.36 \pm 0.87^{\dagger} \\
(13.10)\end{array}$ \\
\hline $50 \mathrm{mM} \mathrm{NaCl}$ & $\begin{array}{l}5.91 \pm 0.39^{d} \\
(21.36)\end{array}$ & $\begin{array}{l}52.44 \pm 2.39^{\circ} \\
(25.30)\end{array}$ & $\begin{array}{l}2.68 \pm 0.07^{f} \\
(6.77)\end{array}$ & $\begin{array}{l}8.63 \pm 0.28^{f} \\
(13.11)\end{array}$ & $\begin{array}{l}45.55 \pm 1.68^{9} \\
(6.52)\end{array}$ \\
\hline $100 \mathrm{mM} \mathrm{NaCl}$ & $\begin{array}{l}7.45 \pm 0.40^{\mathrm{bc}} \\
(52.98\end{array}$ & $\begin{array}{l}58.23 \pm 1.73^{b} \\
(39.14)\end{array}$ & $\begin{array}{l}3.78 \pm 0.09^{c} \\
(50.60)\end{array}$ & $\begin{array}{l}10.43 \pm 0.21^{\mathrm{e}} \\
(36.70)\end{array}$ & $\begin{array}{l}52.83 \pm 1.67^{\mathrm{e}} \\
(23.55)\end{array}$ \\
\hline $150 \mathrm{mM} \mathrm{NaCl}$ & $\begin{array}{l}10.26 \pm 0.43^{a} \\
(110.68)\end{array}$ & $\begin{array}{l}62.87 \pm 1.75^{\mathrm{a}} \\
(50.23)\end{array}$ & $\begin{array}{l}3.78 \pm 0.08^{\circ} \\
(50.60)\end{array}$ & $\begin{array}{l}13.56 \pm 0.40^{b} \\
(77.72)\end{array}$ & $\begin{array}{l}65.37 \pm 1.21^{b} \\
(52.88)\end{array}$ \\
\hline $\begin{array}{l}50 \mathrm{mM} \mathrm{NaCl} \\
+1 \mathrm{mM} \mathrm{SA}\end{array}$ & $\begin{array}{l}4.88 \pm 0.47^{\mathrm{e}} \\
(0.21)\end{array}$ & $\begin{array}{l}50.21 \pm 2.01^{\mathrm{d}} \\
(19.98)\end{array}$ & $\begin{array}{l}3.58 \pm 0.07^{\mathrm{d}} \\
(42.63)\end{array}$ & $\begin{array}{l}11.18 \pm 0.42^{d} \\
(46.53)\end{array}$ & $\begin{array}{l}57.34 \pm 1.26^{d} \\
(34.10)\end{array}$ \\
\hline $100 \mathrm{mM} \mathrm{NaCl}$ & $6.03 \pm 0.51^{d}$ & $54.14 \pm 1.96^{c}$ & $4.09 \pm 0.06^{b}$ & $12.88 \pm 0.39^{c}$ & $62.37 \pm 0.95^{\circ}$ \\
\hline$+1 \mathrm{mM} \mathrm{SA}$ & $(23.82)$ & (29.37) & (62.95) & (68.81) & $(45.86)$ \\
\hline $\begin{array}{l}150 \mathrm{mM} \mathrm{NaCl} \\
+1 \mathrm{mM} \mathrm{SA}\end{array}$ & $\begin{array}{l}8.22 \pm 0.47^{b} \\
(68.79)\end{array}$ & $\begin{array}{l}60.24 \pm 1.79^{b} \\
(43.94)\end{array}$ & $\begin{array}{l}4.57 \pm 0.09^{\mathrm{a}} \\
(82.07)\end{array}$ & $\begin{array}{l}15.01 \pm 0.37^{a} \\
(96.72)\end{array}$ & $\begin{array}{l}77.10 \pm 0.75^{\mathrm{a}} \\
(80.31)\end{array}$ \\
\hline
\end{tabular}

Each value represents the mean $\pm S E$ of five replicates.Values followed by different letters indicate significant differences $(p<0.05)$ according to the Duncan's test. Values in parentheses represent percent variation from the control 
showing a direct correlation with the level of salinity stress. It was enhanced by $111 \%$ over the control under the influence of 150 $\mathrm{mM} \mathrm{NaCl}$ (Table 5). Such an effect possibly involves membrane damage by $\mathrm{H}_{2} \mathrm{O}_{2}$ levels leading to increased generation of hydroxyl radicals and stimulation of lipid peroxidation (Mittler, 2002) and may also involve improper stomatal functioning due to osmotic imbalance and low water potential of leaf. A similar increase in TBARS content under salt stress has been noticed in some earlier studies (Sekmen et al., 2007; Qureshi et al., 2013). However, the interaction of salinity and SA showed a mitigating effect, reducing the extent of salinity-caused damage and containing it maximally by $69 \%$ (Table 5). Possibly, SA application ameliorates the membrane deterioration due to salinity and facilitates the membrane functioning by activating the antioxidant defense arsenal.

Proline accumulation in response to oxidative stress is well known. In the present study, SA application did not exhibit any significant variation (at $p<0.05$ ), but salt treatments significantly increased the proline content of leaves in a dosedependent manner, up to a $50 \%$ increase over the control at 150 $\mathrm{mM} \mathrm{NaCl}$. The interaction of salt and SA treatments significantly reduced the salinity-caused increase in proline content, arresting it around 44\% maximally (Table 5). Proline detoxifies the excess ROS, improves osmotic adjustment, lends protection to biological membranes, and provides stability to enzymes/proteins (Husen, 2010; Iqbal et al., 2014). The increase in proline content due to salt stress, as observed in numerous crop plants, is correlative to plant tolerance to salinity (Mimouni et al., 2016). Observations on G. abyssinica are indicative of the stress-mitigating role of SA. Up-regulation of proline-biosynthesis enzymes (such as pyrroline-5-carboxylate reductase and $\mathrm{y}$-glutamyl kinase) and down-regulation of proline oxidase activity resulted in enhanced proline level in Rauwolfia serpentina, which helped in maintaining the cell turgor under salinity stress (Misra and Misra, 2012).

The SA and salinity treatments, alone and in combination, had a significant effect on SOD, CAT and POX activity at $p<0.05$ (Table 5). Application of SA fostered the activity of these enzymes by $13 \%, 42 \%$ and $13 \%$, respectively, over the control. Similarly, salinity treatments also increased the activity of these enzymes in comparison to control, maximally up to $51 \%, 78 \%$ and $53 \%$, respectively, at $150 \mathrm{mM}$ salt concentration. The collective effect of salinity and SA was synergistic, showing the maximum increase in the enzyme activity by $82 \%, 97 \%$ and $80 \%$, respectively (Table 5). Since the excessive generation of ROS leads to a progressive oxidative damage and ultimately to cell death, plants evolve antioxidant metabolisms involving both enzymatic and nonenzymatic components. SOD initiates detoxification of singlet oxygen by producing $\mathrm{H}_{2} \mathrm{O}_{2}$, to be converted to $\mathrm{H}_{2} \mathrm{O}$ in the subsequent reactions; CAT catalyzes dismutation of two $\mathrm{H}_{2} \mathrm{O}_{2}$ molecules into water and oxygen, while $\mathrm{POX}$ reduces free $\mathrm{H}_{2} \mathrm{O}_{2}$ to water (Aref et al., 2016). In the present study, the control plants had the lowest enzymatic activity, which was enhanced by the salinity as well as SA treatments with the highest activity occurring under their combined influence. SA deficiency facilitates the salinity-induced damages and suppresses the antioxidant strategies. According to Li et al. (2013), SA application (0.5 mM) enhanced salt tolerance in Triticum aestivum through improved transcript level of antioxidant genes and a higher activity of the ascorbate (AsA)-GSH pathway enzyme. On the whole, SA seems to have a crucial role in modulating the cell redox balance and protecting plants from oxidative damage.

In short, salinity stress applied through amended soil caused inhibitory effects on plant growth, biomass accumulation, chlorophyll contents, NR activity and foliar physiology of the species studied. It also promoted proline content and lipid peroxidation, and activated the antioxidant enzymes. However, exogenous SA application ameliorated the adverse effects of salinity and improved the foliar functions and growth attributes. It also had stimulatory effects on the defense arsenal of $G$. abyssinica plants exposed to salt stress.

\section{Acknowledgments}

The authors appreciate the Gondar Agricultural Research Centre, and the departments of Biology and Chemistry at University of Gondar, for providing authentic seeds, and the laboratory/nursery assistance.

\section{References}

Abbaspour, J. and A.A. Ehsanpour: Physiological targets of salicylic acid on Artemisia aucheri Boiss as a medicinal and aromatic plant grown under in vitro drought stress. Bot. Stud., 57, 39 (2016).

Abdin, M.Z., A .Ahmad, N. Khan, I. Khan, A. Jamal and M. Iqbal : Sulphur interaction with other nutrients. In: Sulphur in Plants (Eds.: Y.P. Abrol and A. Ahmad). Kluwer Academic Publishers, Netherlands, pp. 259-274 (2003).

Aref, I.M., P.R. Khan, S. Khan, H.El-Atta, A.I. Ahmed and M. Iqbal: Modulation of antioxidant enzymes in Juniperus procera needles in relation to habitat environment and dieback incidence. Trees Str. Func., 30, 1669-1681 (2016).

Arnon D.I. : Copper enzymes in isolated chloroplasts. Polyphenoxidase in Beta vulgaris. Plant Physiol., 24, 1-15 (1949).

Arshi, A., A. Ahmad, I.M. Aref and M. Iqbal: Effect of calcium against salinity-induced inhibition in growth, ion accumulation and proline contents in Cichorium intybus L. J. Environ. Biol., 31, 939-944 (2010).

Arshi, A., A. Ahmad, I.M. Aref and M. Iqbal: Comparative studies on antioxidant enzyme action and ion accumulation in soybean cultivars under salinity stress. J. Environ. Biol., 33, 9-20 (2012).

Bagheri, R., H. Bashir, J. Ahmad, M. Iqbal and M.I. Qureshi: Spinach (Spinacia oleracea L.) modulates its proteome differentially in response to salinity, cadmium and their combination stress. Plant Physiol. Biochem., 97, 235-245 (2015).

Bashir, F., Mahmooduzzafar, T.O. Siddiqi and M.Iqbal: The antioxidative response system in Glycine max (L.) Merr. exposed to deltamethrin, a synthetic pyrethroid insecticide. Environ. Pollut., 147, 94-100 (2007).

Bashir, H., M.I. Qureshi, M.M. Ibrahim and M. Iqbal: Chloroplast and photosystems: Impact of cadmium and iron deficiency. Photosynthetica, 53, 321-335 (2015).

Bates, L.S., R.P. Waldren and I.D. Teare: Rapid determination of free 
proline for water stress studies. Plant Sci., 39, 205-207 (1973).

Beauchamp, C.O. and I. Fridovich: Superoxide dismutase : Improved assays and an assay applicable to acrylamide gels. Anal. Biochem., 44, 276-287 (1971).

Cakmak, I. and J. Horst: Effect of aluminium on lipid peroxidation, superoxide dismutase, catalase and peroxidase activities in root tips of soybean (Glycine max). Physiol. Plant., 83, 463-468 (1991).

Campbell, W.H.: Nitrate reductase structure, function and regulation: Bridging the gap between biochemistry and physiology. Annu. Rev. Plant Physiol. Mol. Biol., 5, 277-303 (1999).

Chandlee, J.M. and J.G. Scandalios: Analysis of variants affecting the catalase development program in maize scutellum. Theor. Appl. Gene., 69, 71-77 (1984).

Embiale, A., A.Hussein, A.Husen, S. Sahile and K. Mohammed: Differential sensitivity of Pisum sativum L. cultivars to water-deficit stress: Changes in growth, water status, chlorophyll fluorescence and gas exchange attributes. J. Agron., 15, 45-57 (2016).

Fahad, S., S. Hussain, A. Matloob, F.A. Khan, A. Khaliq, S. Saud, S. Hassan, D. Shan, F. Khan, N. Ullah, M. Faiq, M.R. Khan, A.K. Tareen, A. Khan, A. Ullah, N. Ullah and J. Huang: Phytohormones and plant responses to salinity stress: A review. Plant Growth Regul., 75, 391-404 (2014).

Gill, R.A., N. Zhang, B. Ali, M.A. Faroog, J. Xu, M.B. Gill, B. Mao and W. Zhou: Role of exogenous salicylic acid in regulating physiomorphic and molecular changes under chromium toxicity in black and yellow-seeded Brassica napus L. Environ. Sci. Pollut. Res., 23, 20483-20496 (2016).

Hao, J.H., C.J. Dong, Z.G. Zhang, X.L. Wang and Q.M. Shang: Insights into salicylic acid responses in cucumber (Cucumis sativus L.) cotyledons based on a comparative proteomic analysis. Plant Sci., 187, 69-82 (2012).

Hiscox, J.D. and G.F. Israelstam: A method for the extraction of chlorophyll from leaf tissue without maceration. Can. J. Bot., 57, 13-32-1334 (1979).

Husen, A.: Growth, chlorophyll fluorescence and biochemical markers in clonal ramets of shisham (Dalbergia sissoo Roxb.) at nursery stage. New Forests, 38,117-129 (2009).

Husen, A.: Growth characteristics, physiological and metabolic responses of teak (Tectona grandis Linn.f.) clones differencing in rejuvenation capacity subjected to drought stress. Silvae Genet., 59, 124-136 (2010).

Husen, A.: Growth characteristics, biomass and chlorophyll fluorescence variation of Garhwal Himalaya's fodder and fuel wood tree species at the nursery stage. Open J. For., 3,12-16 (2013).

Husen, A., V.K. Mishra, K. Semwal and D. Kumar: Biodiversity status in Ethiopia and challenges. In: Environmental Pollution and Biodiversity (Eds.: K.P.Bharati, A. Chauhan and P. Kumar). Discovery Publishing House Pvt. Ltd., New Delhi, India, Vol 1, pp. 31-79 (2012)

Husen, A., M. Iqbal and I.M. Aref: IAA-induced alteration in growth and photosynthesis of pea (Pisum sativum L.) plants grown under salt stress. J. Environ. Biol., 37, 421-429 (2016).

Husen, A., M. Iqbal and I.M. Aref: Growth, water status and leaf characteristics of Brassica carinata under drought and rehydration conditions. Braz. J. Bot., 37, 217-227 (2014).

Hussein, M., A. Embiale, A. Husen, I.M. Aref and M. Iqbal: Salinityinduced modulation of plant growth and photosynthetic parameters in faba bean (Vicia faba) cultivars. Pak. J. Bot., 49, 867-877 (2017).

Iqbal, N., S.Umar, N.A. Khan and M.I.R. Khan: A new perspective of phytohormones in salinity tolerance: Regulation of proline metabolism. Environ. Exp. Bot., 100, 34-42 (2014).
Jaworski, E.G.: Nitrate reductase assay in intact plant tissue. Biochem. Biophys. Res. Commun., 43,1274-1279 (1971).

Jayakannan, M., J. Bose, O. Babourina, Z. Rengel and S. Shabala: Salicylic acid in plant salinity stress signalling and tolerance. Plant Growth Regul., 76, 25-40 (2015).

Jini, D. and B. Joseph: Physiological mechanism of salicylic acid for alleviation of salt stress in rice. Rice Sci., 24, 97-108 (2017).

Kalaji, H.M., Govindjee, K. Bosa, J. Kościelniak and K. ŹukGołaszewskae: Effects of salt stress on photosystem II efficiency and $\mathrm{CO}_{2}$ assimilation of two Syrian barley landraces. Environ. Exp. Bot., 73,64-72 (2011).

Khan, M.I.R., M. Fatma, T.S. Per, N.A. Anjum and N.A. Khan: Salicylic acid-induced abiotic stress tolerance and underlying mechanisms in plants. Front. Plant Sci. 6, 462 (2015).

Khan, M.I.R., M. Asgher and N.A.Khan: Alleviation of salt-induced photosynthesis and growth inhibition by salicylic acid involves glycinebetaine and ethylene in mungbean (Vigna radiata L.). Plant Physiol. Biochem., 80, 67-74 (2014).

Khodary, S.E.A.: Effect of salicylic acid on the growth, photosynthesis and carbohydrate metabolism in salt-stressed maize plants. $\mathrm{J}$. Agric. Biol., 6, 5-8 (2004).

Kumar, K.B. and P.A. Khan: Peroxidase and polyphenol oxidase in excised ragi (Eleusine coracana Cv. PR 202) leaves during senescence. Ind. J. Exp. Bot., 20, 412-416 (1982).

Li, G., X.Peng, L.Wei and G.Kang: Salicylic acid increases the contents of glutathione and ascorbate and temporally regulates the related gene expression in salt stressed wheat seedlings. Gene, 529, 321$325(2013)$

Liu, S., Y. Dong, L. Xu and J. Kong: Effects of foliar applications of nitric oxide and salicylic acid on salt-induced changes in photosynthesis and antioxidative metabolism of cotton seedlings. Plant Growth Regul., 73, 67-78(2014).

Mimouni, H., S. Wasti, A. Manaa, E. Gharbi, A. Chalh, B. Vandoorne, S. Lutts and H.B. Ahmed: Does salicylic acid (SA) improve tolerance to salt stress in plants? A study of SA effects on tomato plant growth, water dynamics, photosynthesis, and biochemical parameters. OMICS, 20, 180-190 (2016).

Misra, N. and R. Misra: Salicylic acid changes plant growth parameters and proline metabolism in Rauwolfia serpentina leaves grown under salinity stress. American-Eurasian J. Agri. Environ. Sci., 12, 1601-1609 (2012).

Mittler, R.: Oxidative stress, antioxidants and stress tolerance.Trends Plant Sci., 7, 405-410 (2002).

Miura, K., H. Okamoto, E. Okuma, H. Shiba, H. Kamada, P.M. Hasegawa and Y. Murata: SIZ1 deficiency causes reduced stomatal aperture and enhanced drought tolerance via controlling salicylic acid induced accumulation of reactive oxygen species in Arabidopsis. Plant J., 73, 91-104 (2013).

Mutlu, S., Ö. Karadağoğlu, Ö. Atici and B. Nalbantoğlu: Protective role of salicylic acid applied before cold stress on antioxidative system and protein patterns in barley apoplast. Biol. Plant., 57, 507-513 (2013).

Nazar, R., N. Iqbal, S. Syeed and N.A. Khan: Salicylic acid alleviates decreases in photosynthesis under salt stress by enhancing nitrogen and sulfur assimilation and antioxidant metabolism differentially in two mung bean cultivars. J. Plant Physiol., 168, 807-815(2011).

Nazar, R., S. Umar and N.A. Khan: Exogenous salicylic acid improves photosynthesis and growth through increase in ascorbateglutathione metabolism and $\mathrm{S}$ assimilation in mustard under salt stress. Plant Signal Behav., 10, e1003751 (2015).

Netondo, G.W., J.C. Onyango and E. Beck : Sorghum and salinity: I.Response of growth, water relations, and ion accumulation to 
$\mathrm{NaCl}$ salinity. Crop Sci., 44,797-805(2004).

Pitman, M.G. and A. Lauchli: Global impact of salinity and agricultural ecosystem. In: Salinity: Environment, Plants, Molecules (Eds.: A. Lauchli and U. Luttge), Kluwer Academic Publishers, pp. 3-20 (2002).

Qureshi, M.I., M.Z. Abdin, J. Ahmad and M. Iqbal: Effect of long-term salinity on cellular antioxidants, compatible solute and fatty acid profile of Sweet annie (Artemisia annua L.). Phytochemistry, 95, 215-223 (2013).

Rady, M.M. and G.F. Mohamed: Modulation of salt stress effects on the growth, physio-chemical attributes and yields of Phaseolus vulgaris $\mathrm{L}$. plants by the combined application of salicylic acid and Moringa oleifera leaf extract. Sci. Hort., 193, 105-113 (2015).

Rivas-San Vicente, M. and J. Plasencia: Salicylic acid beyond defence: Its role in plant growth and development. J. Exp. Bot., 62, 33213338 (2011)

Sekmen, A.H., I. Türkan and S. Takio: Differential responses of antioxidative enzymes and lipid peroxidation to salt stress in salttolerant Plantago maritima and salt-sensitive Plantago media. Physiol. Plant., 131, 399-411 (2007).

Shi, Q., Z.Bao, Z. Zhu, Q. Ying and Q. Qian: Effects of different treatments of salicylic acid on heat tolerance, chlorophyll fluorescence, and antioxidant enzyme activity in seedlings of Cucumis sativa L. Plant Growth Regul., 48, 127-135(2006).

Siddiqui, S.N., S. Umar, A. Husen and M. Iqbal M: Effect of phosphorus on plant growth and nutrient accumulation in a high and a low zincaccumulating chickpea genotypes. Ann. Phytomed., 4, 66-69 (2015).

Siddiqui, K.S. and A. Husen: Plant response to strigolactones: Current developments and emerging trends. Appl. Soil Ecol., 120, 247-253 (2017).

Silveira, J.A.G., A.R.B. Melo, R.A. Viegas and J.T.A. Oliveira. Salinity induced effects on nitrogen assimilation related to growth in cowpea plants. Environ. Exp. Bot., 46,171-179 (2001).

Stepien, P. and G. Klobus. Water relations and photosynthesis in Cucumis sativus $\mathrm{L}$. leaves under salt stress. Biol. Plant., 50, 610616 (2006).

Taddese, G. and E. Bekele: Saline and saline-sodic soils of Middle Awash Valley of Ethiopia. In: Proc. of the Third Conference of
ESSS, February 28-29 (Eds.: Y. Teshome, M. Eyasu and B. Mintesinot)Addis Ababa, Ethiopia, pp. 97-110 (1996).

Talaat, N.B., A.E. Ghoniem, M.T. Abdelhamid and B.T. Shawky: Effective microorganisms improve growth performance, alter nutrients acquisition and induce compatible solutes accumulation in common bean (Phaseolus vulgaris L.) plants subjected to salinity stress. Plant Growth Regul., 75, 281-295 (2015).

Tsige, H., T. Gebrasellasie and T. Mamo: Assessment of salinity/sodicity problems in abaya state farm, Southern Rift Valley of Ethiopia. Ethiop. J. Na. Resour., 2,151-163 (2000).

Umar, S., Anjana and M. Iqbal: Interactive effects of potassium and nitrogen nutrition on physiological use efficiency of nitrogen and crop yield. In: Nitrogen Use Efficiency in Plants (Eds.: V. Jain and P.A. Kumar), New India Publishing Agency, New Delhi, pp.125-155 (2011).

Umar, S., I. Diva, N.A. Anjum and M. Iqbal: Effect of potassium application on NaCl-induced changes in mustard (Brassica campestris L.). In: Proceedings of IPI-OUAT-IPNI International Symposium-2009 (Ed.: M.S. Brar), Bhubaneswar, pp. 384-387 (2010).

Yildiztugay, E., C. Ozfidan-Konakci, M. Kucukoduk and Y. Duran: Variations in osmotic adjustment and water relations of Sphaerophysa kotschyana: Glycine betaine, proline and choline accumulation in response to salinity. Bot. Stud., 55, 6 (2014).

Yousuf, P.Y., A. Ahmad, I.M. Aref, M. Ozturk, Hemant, A.H. Ganie and M.lqbal: Salt-stress-responsive chloroplast proteins in Brassica juncea genotypes with contrasting salt tolerance and their quantitative PCR analysis. Protoplasma, 253, 1565-1575 (2016a).

Yousuf, P.Y., A. Ahmad, A.H. Ganie and M. Iqbal: Salt stress-induced modulations in the shoot proteome of Brassica juncea genotypes. Environ. Sci. Pollut. Res., 23, 2391-2401 (2016b).

Yousuf, P.Y., A. Ahmad, A.H. Ganie, O. Sareer, V. Krishnapriya, I.M. Aref and M. Iqbal: Antioxidant response and proteomic modulations in Indian mustard grown under salt stress. Plant Growth Regul., 81, 31-50 (2017).

Yousuf, P.Y., A. Ahmad, Hemant, A.H. Ganie, I.M. Aref and M. Iqbal: Potassium and calcium application ameliorates growth and oxidative homeostasis in salt-stressed Indian mustard (Brassica juncea) plants. Pak. J. Bot., 47, 1629-1639 (2015). 